Tohoku J. Exper. Med., 1961, 73, 247-248

\title{
The Method How to Eliminate Inhibitors in Human Serum for the Hemagglutination Inhibition Titration when an Asian P Virus was Used as an Antigen
}

(Studies on Several Inhibitors against Influenza Viruses, 5th Report)

By

Hiroshi Sasaki and Yutaka Kabata

Department of Bacteriology, School of Medicine, Tohoku

Univercity, Sendai; Director : Prof. N.Ishida

(Received for publication, September 14, 1960)

In detecting antibodies against influenza virus, hemagglutination inhibition titration still remains as a most handy and useful procedure. However, as many people noticed at the time of outbreak of Asian flu, precautions must be taken in order to eliminate non-specific inhibitors contained in the serum specimens without any destruction of antibody. The urgent problem at the time of outbreak was dissolved by using $\mathrm{KIO}_{4}$ to remove these inhibitors. However, some destruction of antibody was later recognized with this technique. The work presented here ${ }^{11}$ was carried out to establish the standard procedure to eliminate all kinds of nonspecific inhibitors contained in human sera.

The result pointed out that when a large amount of cholera filtrate (No. 558) was added to the specimen and left overnight at $37^{\circ} \mathrm{C}$, all inhibitors were removed as was the case with $\mathrm{KIO}_{4}$ treatment. Moreover, it was concluded that the cholera filtrate is more suitable for general purposes, i.e. to destroy inhibitors of the serum or organs of experimental animals except serum of guinea pigs.

As already noticed, inhibitors against Asian $\mathrm{P}$ virus detectable in human serum (tentatively called as $\alpha^{\prime}$-inhibitor) was resistant to RDE action, but susceptible to the action of cholera filtrate. Thus the difference between cholera filtrate and RDE was studied further, and the term $\alpha^{\prime}$-enzyme was proposed to the particular agent which destroys $a^{\prime}$-inhibitor or inhibitors. Kinetic studies revealed difference between $\alpha$ - and $\alpha^{\prime}$-enzyme. Optimum amount of $\mathrm{Ca}$ ion necessary as the co-factor was also different in each. However, heat lability of $\alpha^{\prime}$-enzyme was most remarkable in differentiating the enzyme from $\alpha$-enzyme. Electrophoretic mobility was also different.

Production conditions and standardization procedures of the cholera filtrate 
were also described. When the experimental conditions proposed here were carefully followed, the production of RDE ( $\alpha$-enzyme), $\alpha^{\prime}$-enzyme, and of $\beta$-enzyme in the filtrate was constant during the experimental period of 6 months.

\section{References}

1) Sasaki, H,, Virus, 1959, 9, 404. 